\title{
Studies of Physical Structure of Fog
}

\author{
By Toshiichi Okita \\ Department of Industrial Health and Hygiene, Institute of Public Health
}

(Manuscript received 8 November 1961)

\begin{abstract}
Some results on the drop size distribution of radiation fog near the ground at Asahikawa measured by gravity settling method are presented in Part 1 . The concentration of small droplets with radii below 20 microns gradually increases until 10 to 50 minutes after the formation of the fog, then it has nearly constant value. At the base of the thick fog the large droplets with radii larger than 50 microns appear at the later stage of the development of the fog. In the shallow fog, on the other hand, the increase or decrease of the concentration of large and small droplets occurs concurrently.

The influence of air temperature on the structure of fog is also studied. It is found that when the air temperature is above freezing the mean volume radius is 12.5 to 15 microns In the majority of the cases when the air temperature is below $-5^{\circ} \mathrm{C}$ the mean volume radius is about 7.5 microns. In the winter fog the low liquid water contents between $10^{-4}$ and $10^{-2} \mathrm{~g} / \mathrm{m}^{3}$ are frequently found. It is suggested that in winter fog a large number of very fine particles are present and obscure the visibility.

The measurements by means of a hand operated impactor and water-blue dye coated film reveal that many small droplets of radii less than 2 microns are present frequently in winter fog especially in smog and steam fog. Their results are shown in Part 2. It is further found that the local difference of the structure of fog and the effect of river steam are small in well developed radiation fog.
\end{abstract}

\section{Part 1. Structure of Radiation Fog near the Ground}

\subsection{Introduction}

The physical structure of fog and stratus cloud is one of the important problems in meteorology, particularly concerning with smog. Although the samplings of fog- and cloud-droplets have been made by many investigators, few systematic investigations of the physical structure of fog and stratus cloud have been undertaken.

As Asahikawa is situated in a basin radiation fog frequently occurs and annual mean value of fog day is about 90 days. Moreover, severe smog frequently occurs in winter. Therefore the study of radiation fog is also of practical importance for the prevention of smog.

In the period from September, 1957 to February, 1958, the measurements of the size distribution of radiation fog droplets were made on the ground. The gravity settling method was employed for the sampling (Okita, 1961).

\subsection{Observations on September 11, 1953}

As fog occurred at about 0200 JST the droplet samplings were made from 0339 JST at Shunkocho (Fig. 1.1). Fig. 1.2 shows the variation of the concentration of fog droplets in several size groups. At the top of the figure the mean volume radius (M.V.R.) and maximum droplet radius (M.D.R.) in each sample are also shown. From the figure it is found that small droplets with radii below 20 microns show no large variation in concentration. The larger droplets, on the other hand, appeared in the later stage of the development of the fog and gradually increased in concentration. The concentrations of the large droplets were at their maximum 


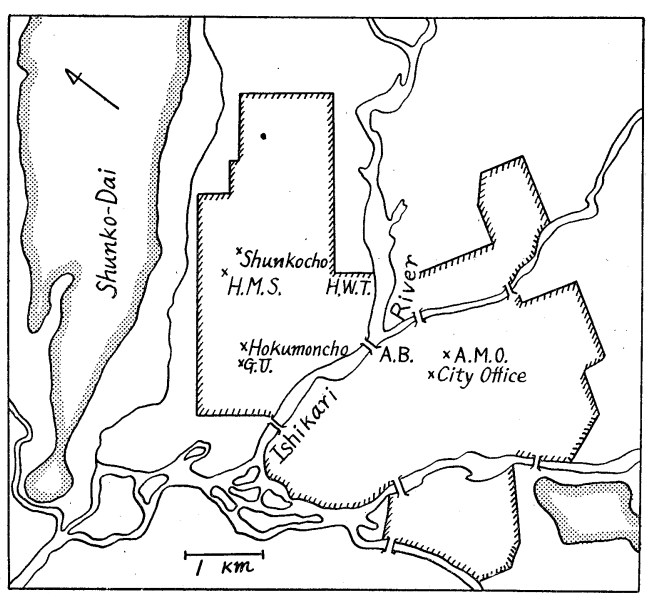

Fig. 1.1. Asahikawa.

H.W.T.: Hokusei watch tower

G.U.: Gakugei University

H.M.S. : Hokusei middle school

A.B. : Asahi bridge

A.M.O. : Asahikawa Meteorological Observatory

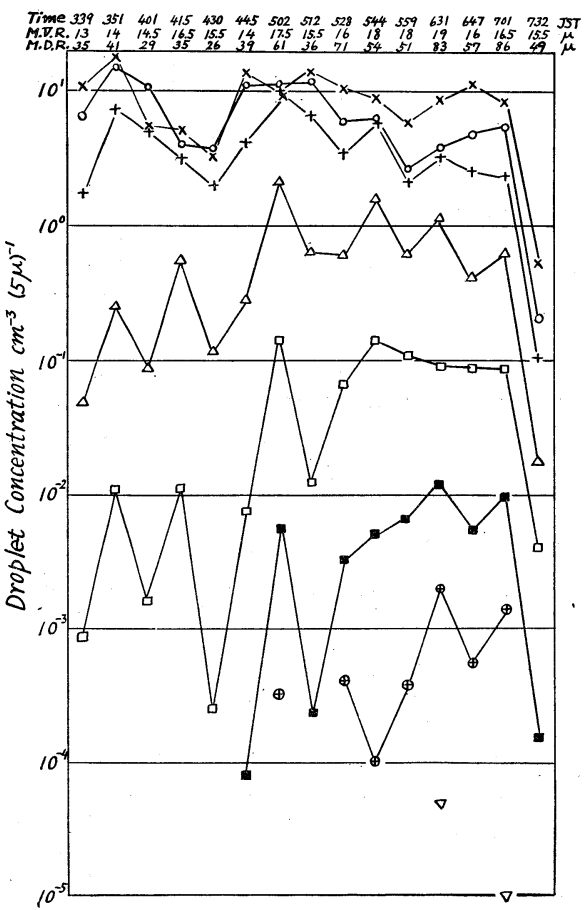

Fig. 1.2. Variation of concentrations of radiation fog droplets on Sep. 11, 1957.

Range of radius $(\mu)$

$\begin{array}{cccc}\odot & 3-5 & \square & 25-35 \\ \times & 5-10 & & 35-50 \\ \bigcirc & 10-15 & \oplus & 50-75 \\ + & 15-20 & & 75-100 \\ \triangle & 20-25 & & \end{array}$

from 0631 to 0701 JST, when the droplets of radius as large as 85 microns were found. It is interesting to note that at 0732 JST, when the fog was dissipating, the rate of decrease of the droplet concentration was the same irrespective of fog size. It may be said that Fig. 1.2 is a typical example of the variation of droplet size and concentration at the base of deep radiation fog.

\subsection{Observations on September 22, 1957}

At Shunkocho fog appeared at about 0340 JST, then the samplings were made from 0349 JST. The fog layer, however, did not develop upward with estimated thickness between 50 and $100 \mathrm{~m}$. Fig. 1.3 indicates that the increase or decrease of the concentration of large and small droplets occurred concurrently. The concentration increased till about $0500 \mathrm{JST}$, then it gradually decreased. Such a variation will be typical for shallow fog.

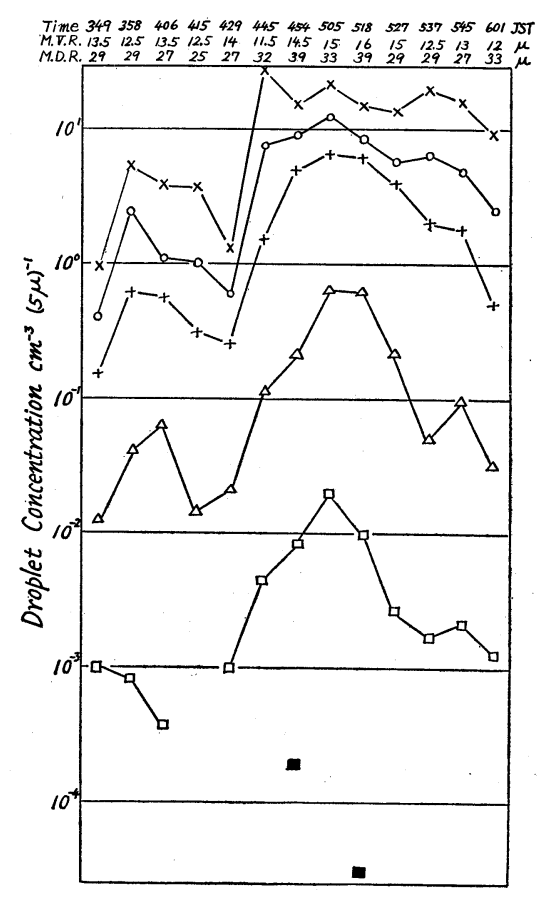

Fig. 1.3. Variation of concentrations of radiation fog droplets on Sep. 22, 1957.

Symbols in the figure are the same as in Fig. 1.2. 


\subsection{Observations on September 23, 1957}

At Shunkocho fog occurred at about 0404 JST. The concentration of small droplets increased until $0456 \mathrm{JST}$, then it had nearly constant value (Fig. 1.4). The droplets with

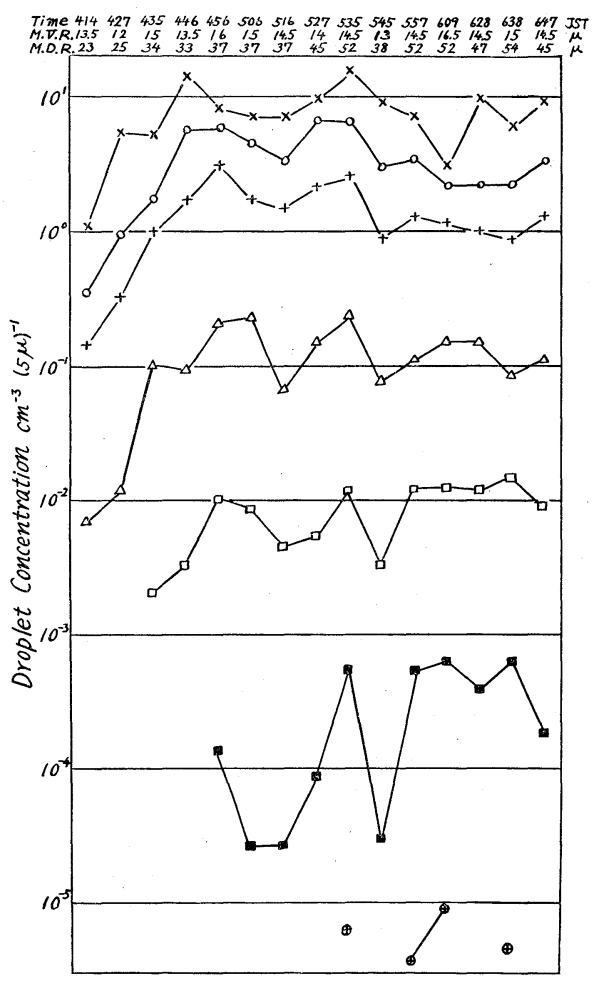

Fig. 1.4. Variation of concentrations of radiation fog droplets on Sep. 23, 1957. Symbols in the figure are the same as in Fig. 1.2.

radii between 25 and 50 microns appeared 20 to 50 minutes after the occurrence of the fog. The droplets of radii larger than 50 microns appeared at the later stage of the fog development. This type of variation is similar to that on September 11. However, as the maximum droplet radius, 54 microns, is smaller than that on September 11, it is supposed that the fog layer is less deep on September 23 than on September 11.

\subsection{Obervations on January 16 and February 7, 1958}

Fig. 1.5 shows two examples of the variation of droplet size distributions of winter fog. Fog occurred at about 2100 JST of
January 16, 1958 and the samplings were made between 2210 and 2250 JST on the $30 \mathrm{~m}$ high Hokusei Watch Tower (Fig. 1.1). The fog first appeared at some level above the ground and then descended to the ground. It is interesting to note that despite the air temperature as low as $-10^{\circ} \mathrm{C}$ the large droplet with radius 63 microns was found in the fog. The liquid water contents were between 0.2 and $0.45 \mathrm{~g} / \mathrm{m}^{3}$. The high concentration of small droplets as many as 300 $\mathrm{cm}^{-3}$ was observed.

As fog occurred at about 0500 JST on February 7, 1958 the samplings were made from 0538 to 0639 JST on the roof of the Hokusei Middle School at $20 \mathrm{~m}$ above the ground (Fig. 1.1). Many small droplets with radii below 5 microns were also found. It is of interest to note that at about 0603 JST the concentration of smaller droplets rapidly decreased concurrently with the appearance of larger droplets of radii above 15 microns, then the concentration returned to its original value as the large droplets disappeared. However, it is uncertain what happened at that time.

\subsection{The influence of air temperature on the structure of fog}

Comparing Figs. 1.2 to 1.4 with Fig. 1.5 it is found that when the air temperature is above $5{ }^{\circ} \mathrm{C}$ very few small droplets with radii below 5 microns are present in the fog. When the air temperature is below $-10^{\circ} \mathrm{C}$, on the other hand, such small droplets are contained in concentration above $100 \mathrm{~cm}^{-3}$. For the droplets with radii above 10 microns the concentration is usually larger in autumn- than in winter-fog.

The relationship between the mean volume radius (M.V.R.) of fog droplets and mean air temperature shown in Fig. 1.6 also indicates more clearly the above results. The data in the figure are obtained in the period from 1952 to 1957 for autumn fogs and from 1958 to 1960 for winter fogs. The gravity settling method gives inaccurate values for the concentration of small droplets of radii below 3 microns (Okita, 1961). Then the mean volume radius, which is unaffected by the inaccuracy of the measure- ment of small droplet concentration, is used to represent 


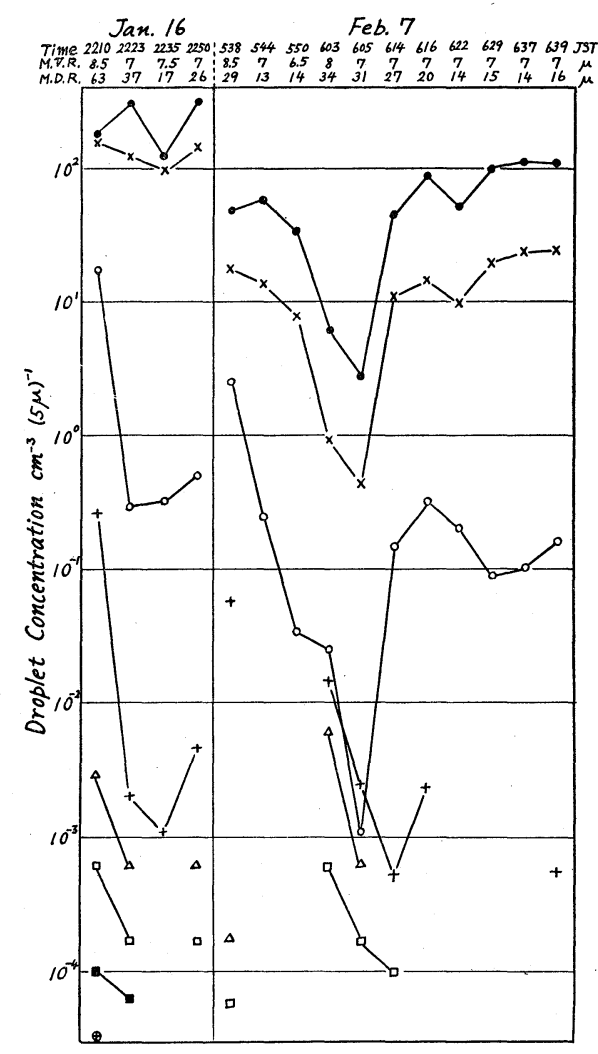

Fig. 1.5. Variation of concentration of radiation fog droplets on Jan. 16 and Feb. 7, 1958. Symbols in the figure are the same as in Fig. 1.2.

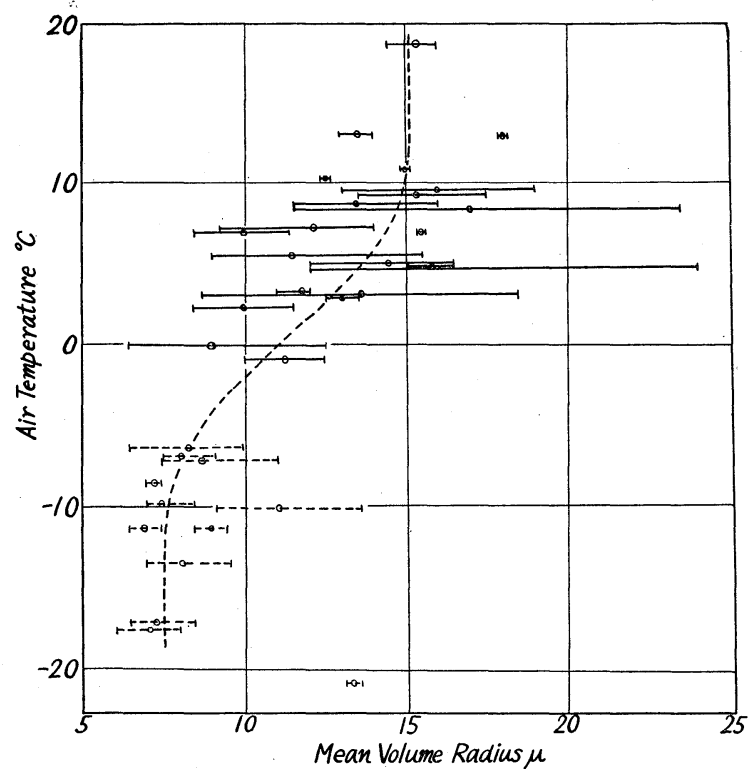

Fig. 1.6. Relationship of mean volume radius versus air temperature.

_- Range of M.V.R., the mean droplet size.

Although a fog may have wide range of mean volume radius from its formation to dissipation, Fig. 1.6 shows that when the air temperature is above $2^{\circ} \mathrm{C}$ the mean value of mean volume radius is about 12.5 to 15 microns. In the majority of the cases when the air temperature is below $-5^{\circ} \mathrm{C}$ and fog occurs on the snow cover the mean value is about 7.5 microns. In these cases the fog seems to be confined in shallow layer. In the thick fog the mean volume radius is about 10 microns even when the air temperature is below $-10^{\circ} \mathrm{C}$.

For the droplet samples of autumn fog, which contain relatively few small droplets, both linear mean radius and mean volume radius can be determined. The relationship between them is shown in Fig. 1.7. The figure shows that there is close relation between the two kinds of radius for the range of mean volume radius below 15 microns. For the mean volume radius above 16 microns, on the other hand, the plots in the figure diverge significantly from a line.

Fig. 1.8 shows the relationship between mean air temperature and liquid water content of fog for the samples shown in Fig. 1.6. Then, of course, all the samples are obtained near the ground. In the majority

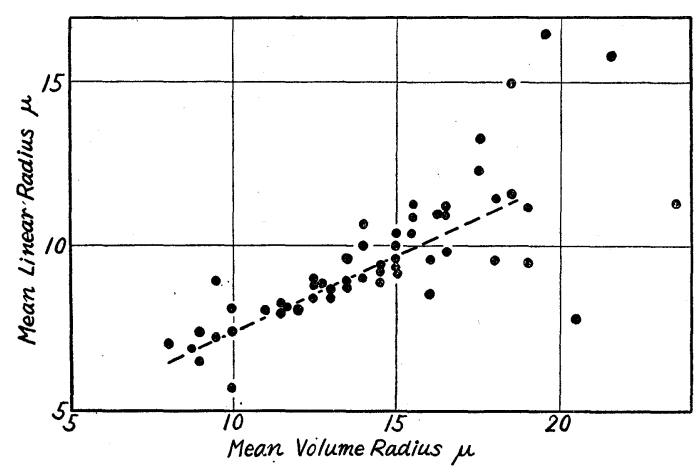

Fig. 1.7. Relationship of mean linear radius versus mean volume radius of radiation fog droplets.

of the cases the liquid water content has the values between 0.01 and $0.5 \mathrm{~g} / \mathrm{m}^{3}$ independently of air temperature. In the winter fog which occurs when the air temperature is below $-6^{\circ} \mathrm{C}$, the low liquid water contents between $10^{-4}$ and $10^{-2} \mathrm{~g} / \mathrm{m}^{3}$ are frequently found, which 


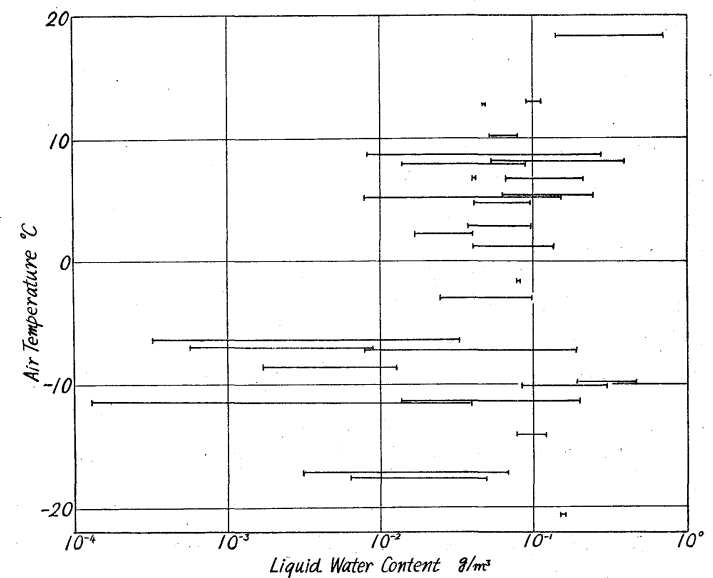

Fig. 1.8. Relationship between mean air temperature and liquid water content of radiation fog.

seems to be a feature of winter shallow fog. According to the Radford's diagram (Houghton and Radford, 1938) which relates liquid water content and horizontal visibility, the minimum liquid water content corresponding to the maximum value of visibility, $1,000 \mathrm{~m}$, in fog is $0.02 \mathrm{~g} / \mathrm{m}^{3}$. Then it is suggested that in winter fog a large number of very fine particles are present and obscure the visibility.

\section{Part 2. The Observations of Size Distribu- tion of Small Droplets in Radiation and Other Fogs}

\subsection{Introduction}

The investigation of small droplets with radius about one micron in cloud and fog is one of the important subjects of cloud physics. Usually the investigators have found very few such small droplets. But according to the Eldridge's indirect measurements of droplet size distribution by means of infrared transmissometer (Eldridge, 1957) small droplets with radii about 0.5 micron are contained in growing stratiform cloud in concentration more than 10,000 per $\mathrm{cm}^{3}$. Kumai (1951) found many small particles in the branches of dendritic ice crystals by means of electron-microscope. He further supposed that the particles are the nuclei of minute cloud droplets which are collected by the ice crystals while the latter are growing. Kamiyama and Moriguchi (1952) made the droplet samplings on the fine methylmetacrylate fibre in sea fog. They found that the number of small droplets of size 0.3-1.2 microns captured on the fibre was about ten times as large as the number of ordinary fog droplets.

As described in Part 1 it is supposed that winter fog, especially "smog", contains such small droplets. Then the investigations of the size distribution of small droplets were done in radiation and other fogs using the water-blue film technique (Okita, 1958).

\subsection{Sampling technique}

The measurements of the small droplets in fog were made by means of following technique. The hand operated impactor with hole diameter one $\mathrm{mm}$ shown in Fig. 2.1 was

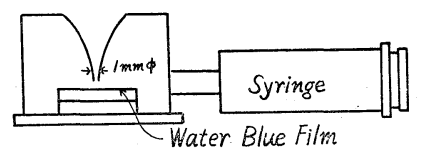

Fig. 2.1. Impactor.

used for the collection of the droplets. A thin water-blue dye coated celluloid film with area $1 \times 1 \mathrm{~cm}^{2}$ was attached to a glass slide and placed under the hole. The fog droplets were collected on the film when fog air was drawn by means of a hand-operated glass syringe. The volume of the syringe was 20 $\mathrm{cm}^{3}$. Usually 10 to $1,000 \mathrm{~cm}^{3}$ of fog air was drawn depending on the density of the fog. The samplings of the droplets were always made in Asahikawa.

It is frequently mentioned that if the air is drawn through a narrow hole, rapid increase of air velocity would result in adiabatic cooling of the air, then condensation would take place in the air stream. Then a brief estimation of the effect of the cooling will be made. Usually $10 \mathrm{~cm}^{3}$ of fog air is drawn in one second, so that the mean air velocity at the hole of diameter one $\mathrm{mm}$ is $12.7 \mathrm{~m} / \mathrm{sec}$. If it is assumed that the air is saturated and is cooled adiabatically the supersaturation of 0.006 to 0.008 per cent will be attained if the air temperature is between 0 and $-20^{\circ} \mathrm{C}$. However, as the time for the air to pass through the hole is only $10^{-3}$ second or less, even if the nucleation occurs, the time is not 
enough for the new droplets to grow to onemicron size droplets. This conclusion is confirmed by the measurements in the fog on October 22, 1959 and on September 29, 1960, when very few droplets of radii between 0.5 to 2 microns were found even when the fog was growing.

The collection efficiency of the impactor was measured by Ranz and Wong (1952), their result being shown in Fig. 2.2. In the

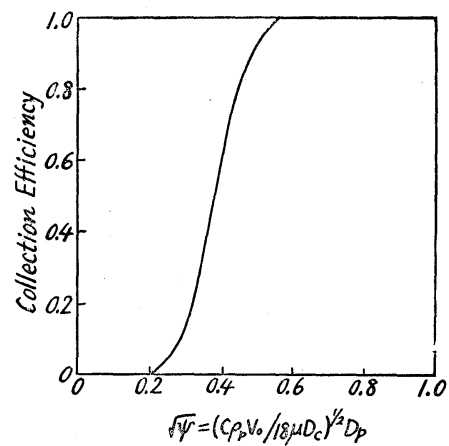

Fig. 2.2. Collection efficiency of impactor according to Ranz and Wong.

figure the collection efficiency is plotted against $\sqrt{\psi}=\left(C \rho_{p} v_{0} / 18 \mu D_{c}\right)^{1 / 2} D_{p}$, where $C$ is the empirical correction factor for the resistance of air opposed to the movement of small particles, which is expressed by $C=1.00+$ $0.16 \times 10^{-4} / D_{p}$.

$\rho_{p}$ is the density of aerosol particles in $\mathrm{g} / \mathrm{cm}^{3}, v_{0}$ the velocity of aerosol jet in $\mathrm{cm} / \mathrm{sec}$, $D_{p}$ the effective diameter of aerosol particle in $\mathrm{cm}, \mu$ the viscosity of air in poise and $D_{c}$ is the diameter of round jet in $\mathrm{cm}$. If the fog air of volume $10 \mathrm{~cm}^{3}$ is drawn through a round hole of diameter one $\mathrm{mm}$ in one second the mean air velocity at the hole is $12.7 \mathrm{~m} / \mathrm{sec}$. The figure shows that the droplets of radii above 1.4 microns are completely captured. The collection efficiency is about 50 per cent for one micron-radius droplets. Therefore the droplet concentrations shown in the following figures, which are obtained under the assumption that the collection efficiency is unity, give only relative values for the droplets of radii below 2 microns and it is likely that more small droplets are present in the fog.

\subsection{Observations on December 10,1959 (winter fog associated with air pollution)}

As fog occurred at about 2200 JST on December 10, 1959 the droplet samplings were made from to 2200 to 2314 JST at Shunkocho (Part 1, Fig. 1.1). The smoke from the chimneys of many houses was mixed with the fog, so that the fog may be called "smog". It is found that large carbon particles of diameters above 10 microns are contained in about half of the stains of large fog droplets with radii above 12.5 microns. These large carbon particles would act as the nuclei of the large droplets.

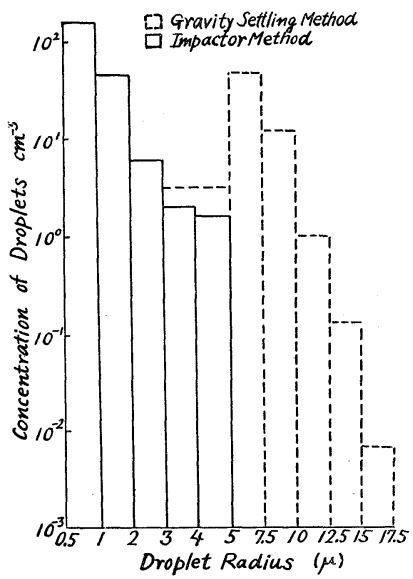

Fig. 2.3. Droplet size distribution at 2250 JST, Dec. 10, 1959.

One example (2250 JST) of droplet size distributions is shown in Fig. 2.3. In the figure the size distributions obtained by gravity settling method is also shown (Okita, 1961). These two methods give the same concentration for droplets of radii between 3 and 5 microns. For the droplets with radii larger than 5 microns gravity settling method gives larger concentration than by impactor method, which indicates that the collection efficiency of the impactor reduces also for large droplets. The gravity settling method gives inaccurate result for the small droplets of radii less than 3 microns, which is due to the fact that the fall velocity of the small droplets is very small.

The figure indicates that the fog occurred in polluted air contains small droplets of radii below two microns in concentration 
above several hundred per $\mathrm{cm}^{3}$ of air. This type of size distribution continued more than two hours, which reveals that the small droplets were stable in the fog. The air temperature at $2230 \mathrm{JST}$ was $-13.7^{\circ} \mathrm{C}$.

Findeisen (1932) measured the droplet size distribution of radiation fog occurred in winter at Hamburg by means of photographic method. One of his distributions is shown in Fig. 2.4. His distribution curve has a peak with droplet radius below 2 microns. The result obtained by Liddell and Wootten (1957) in winter fog at Porton shown in Fig. 2.5 also indicates that more than half of the droplets have radii below one micron. Therefore, from these observations it is concluded that the presence of very small droplets with radii one to two microns is one of the characteristics of winter fog, especially of smog.

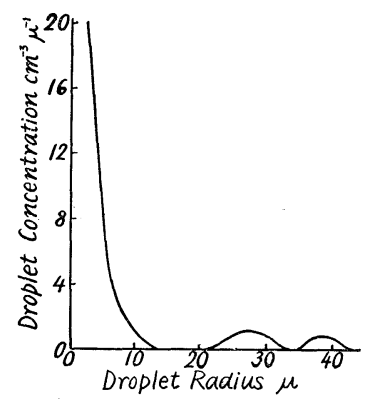

Fig. 2.4. Droplet size distribution of radiation fog at Hamburg, Jan. 13, 1931.

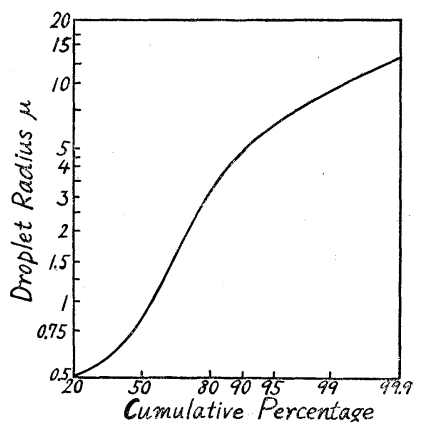

Fig. 2.5. Droplet size distribution of fog at Porton, Dec. 15, $1540 \mathrm{hr}, 1954$.

\subsection{Observations on December 3, 1959 and on March 13, 1960 (frontal fog)}

As a cyclone passed over Hokkaido on
December 3, 1959, steady rain fell at Asahikawa, the three-hour intensity of the rain being 5.2 and $2.5 \mathrm{~mm}$ from 1500 to 1800 JST and 1800 to 2100 JST respectively. At about 1730 JST fog occurred in the rain and although Asahikawa was in the center of the cyclone there was little wind. The samplings of fog droplets were made from 1740 to

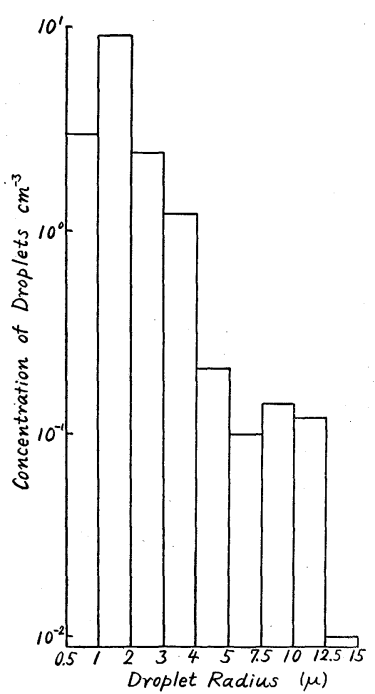

Fig. 2.6. Droplet size distribution at 1814 JST, Dec. 3, 1959.

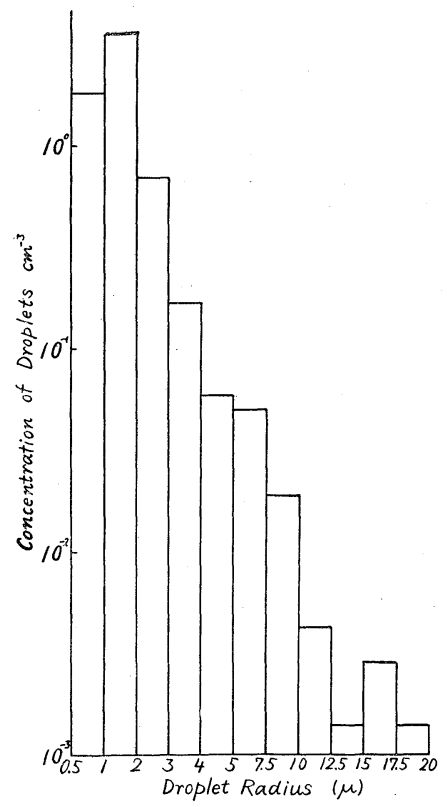

Fig. 2.7. Droplet size distribution at 0253 JST, Mar. 13, 1960. 
1818 JST at Shunkocho. One of the droplet size distributions is shown in Fig. 2.6. The air temperature at $1800 \mathrm{JST}$ was $-1.9^{\circ} \mathrm{C}$.

A cyclone also passed over Hokkaido and light rain fell in the midnight of March 12 to 13,1960 , its intensity between 2400 and 0300 JST being $0.3 \mathrm{~mm}$. Thin fog occurred at midnight and there was little wind. The air temperature at $0300 \mathrm{JST}$ was $2.7^{\circ} \mathrm{C}$. The samplings of fog droplets were made at about $0300 \mathrm{JST}$ and one of the measured droplet size distributions is shown in Fig. 2.7.

The records of radio-sounding made at Sapporo show the temperature inversions with top at about 140 and $320 \mathrm{~m}$ at $2100 \mathrm{JST}$ of December 3, 1959 and of March 12, 1960 respectively. Therefore it may be supposed that the temperature inversion was present also over Asahikawa. The staffs of the Asahikawa Local Meteorological Observatory said that they frequently observed the cold air stagnating in the lowest layer over the Kamikawa Basin. Therefore the fog seems to be of frontal fog type intensified by nocturnal radiation. It is further noticed that the size distributions on these days have the same form. Therefore it may be concluded that the distributions shown in Figs. 2.6 and 2.7 are typical in frontal fog. These distributions also indicate the relatively high concentrations of small droplets.

2.5 Observation on October 22, 1959 and On September 29, 1960 (autumn fog)

Shallow fog occurred at about 0150 JST

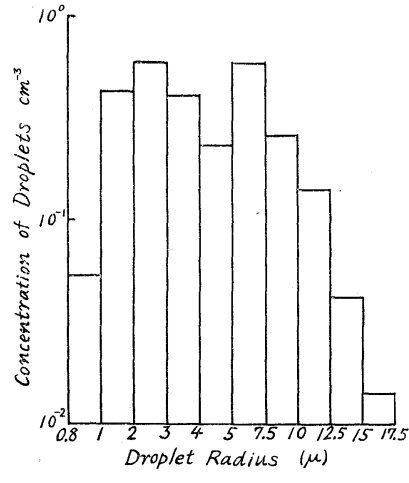

(a) at $0159 \mathrm{JST}$

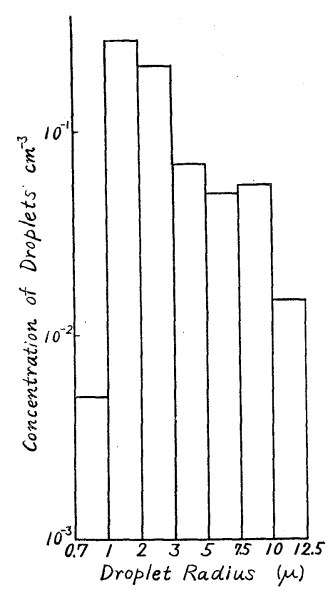

(b) at $0230 \mathrm{JST}$
Fig. 2.8. Droplet size distributions on Oct. 22, 1959. on October 22, 1959 at the ground of the Gakugei University (Part 1, Fig. 1.1) but it disappeared at about 0210 JST. After 0223 JST the fog appeared again and developed. The air temperature at $0235 \mathrm{JST}$ was $0.7^{\circ} \mathrm{C}$. The samplings of fog droplets were made at 0159 and $0230 \mathrm{JST}$, their results being shown in Fig. 2.8 .

Fog occurred at about 0407 JST on September 29, 1960 at Shunkocho. The thickness of the fog was estimated to be 30 to $40 \mathrm{~m}$ as the stars were visible through the fog. One of the droplet size distributions (at 0411 JST) is shown in Fig. 2.9. The air temperature at $0300 \mathrm{JST}$ was $2.8^{\circ} \mathrm{C}$.

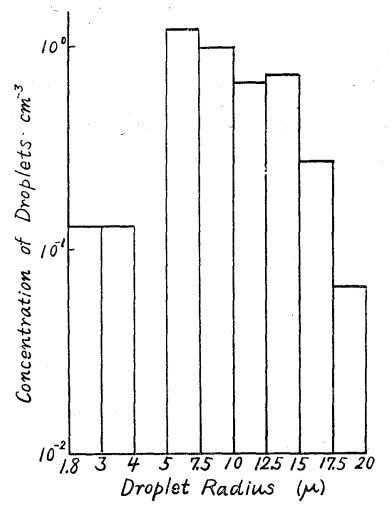

Fig. 2.9. Droplet size distribution at 0411 JST, Sep. 29, 1960.

It is evident from Figs. 2.8 and 2.9 that the concentration of small droplets in the initial stage of radiation fog in autumn is very small.

\section{6 Observations on March 16, 1960 (steam fog)}

Steam fogs frequently occur over the Ishikari River in cold winter. From 0615 to 0715 JST on March 16, 1960 the samplings of steam fog droplets were made on the bank near the Asahi Bridge (Part 1, Fig. 1.1). The droplet size distribution (0640 JST) shown in Fig. 2.10 indicates that more than 80 per cent by number of the droplets are of less than 2 micron radius. Therefore it is evident that radiation and steam fog have quite different physical structure. The air temperature during the samplings was about $-14.3^{\circ} \mathrm{C}$. 


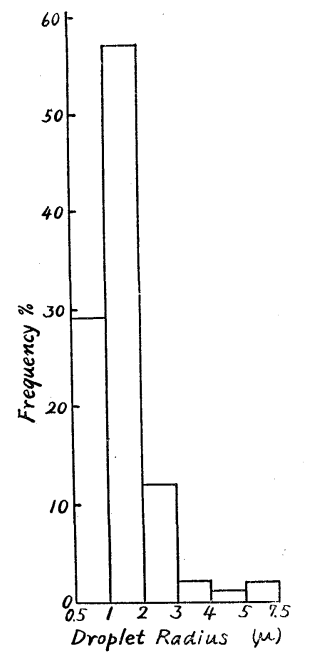

F1g. 2.10. Droplet size distribution at 0640 JST, Mar. 16, 1960.

\subsection{Observations on January $22, \quad 1959$ (ground fog)}

In the period of 0834 to 0850 JST a shallow ground fog about $1.5 \mathrm{~m}$ thick developed over Hokumoncho and other area (Part 1, Fig. 1.1). Visibility in the fog was between 200 and $300 \mathrm{~m}$. Several samplings were made in the fog. Fig. 2.11 is one of the droplet size dis-

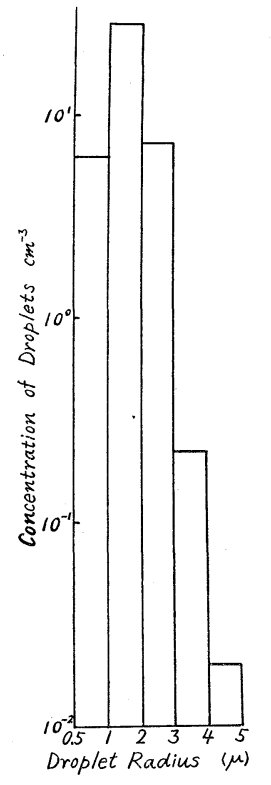

Fig. 2.11. Droplet size distribution at 0840 JST, Jan. 22, 1959. tribution of the ground fog. The ground fog consisted of the droplets of radii less than 2.5 microns and has the similar structure as steam fog. The air temperature during the observations was about $-10.0^{\circ} \mathrm{C}$.

2.8 Observations on March 30 and on October 29 in 1959 (fog in dissipating stage)

On March 30, 1959 fog occurred at about 0220 JST but gradually dissipated after 0730

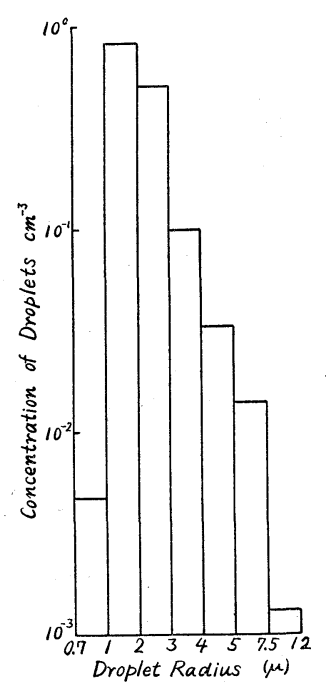

Fig. 2.12. Droplet size distribution at 0748 JST, Mar. 30, 1959.

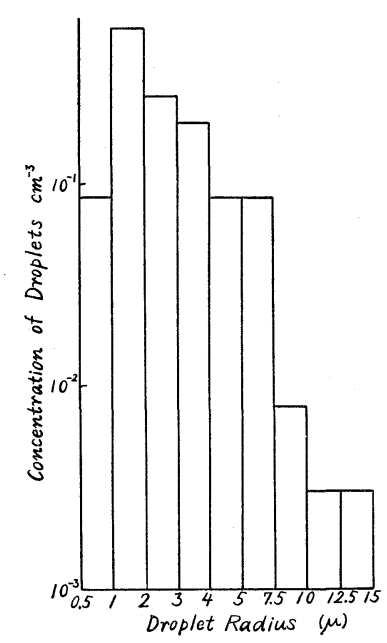

Fig. 2.13. Droplet size distribution at 0711 JST, Oct. 29, 1959. 
JST. The samplings were made from 0745 to 0759 JST. In this case and on October 29 the impactor with the diameter of hole 3 $\mathrm{mm}$ was used. During the samplings the visibility was about one $\mathrm{km}$ and the air temperature about $3.0^{\circ} \mathrm{C}$. Fig. 2.12 shows the droplet size distribution at 0748 JST.

Fog was formed at 0310 JST on October 29,1959 , but it began to dissipate at about $0700 \mathrm{JST}$. The droplet samplings by means of large hole impactor were made between 0711 and 0732 JST. Fig. 2.13 shows the droplet size distribution at 0711 JST. The mean visibility during the samplings was about $500 \mathrm{~m}$ and the air temperature at 0700 JST was $6.6^{\circ} \mathrm{C}$.

The distributions shown in Figs. 2.12 and 2.13 have the same form with a peak with radius about 1.5 microns. However, as it is supposed that the collection efficiency of one micron-size droplets by the large hole impactor is considerably small, it is expected that more droplets of this size were present in the fog.

\subsection{Observations on March 10, 1960}

Fog occurred at about 0100 JST on March 10, 1960. The samplings of fog droplets were made at three different places in the Asahikawa City to examine the local difference of the structure of the fog. The places are Shunkocho (residential quarter), city office (central part of city) and the Asahi Bridge (river side) (see Fig. 1.1). Both the impactor and gravity settling methods were employed.

Three examples of droplet size distributions are shown in Figs. 2.14 (a) to (c) and Table 2.1 lists some properties of the fog. There were rather few small droplets of radii less than 2 microns. Comparing with the size distributions on December 10 shown in Fig. 2.3 it is concluded that numerous small droplets are formed in the polluted air in the evening. However, at midnight and in the early morning, when the chimneys of most of the houses do not emit smoke, the concentration of both the smoke and small droplets gradually decreases. The values of visibility in the table are calculated from the droplet size distributions using the equation

$$
V=\frac{3.91}{k_{s}}, \quad k_{s}=K_{s} \pi \Sigma r^{2} n
$$

where $V$ is visibility, $k_{s}$ scattering coefficient, $r$ droplet radius and $n$ is droplet concentration. The value of $K_{s}$ is approximately equal to 2 for large fog droplets. The calculated values are approximately in agreement with the the observed visibility.

Table 2.1 shows that there is little difference of the structure of fog at three different places, except that the values of mean volume

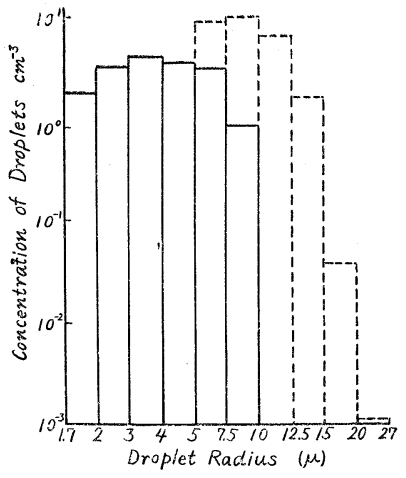

(a) Shunkocho, 0310-0330 JST

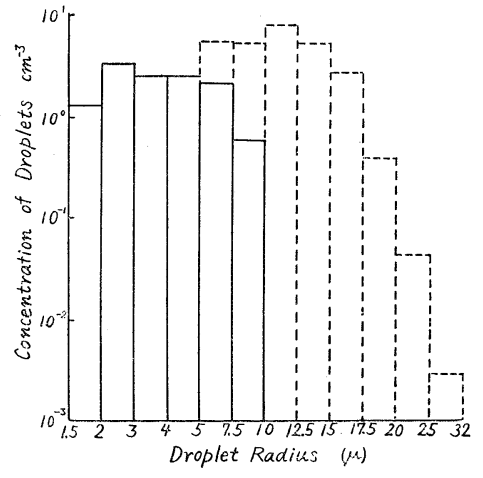

(c) Asahi Bridge, 0557-0606 JST

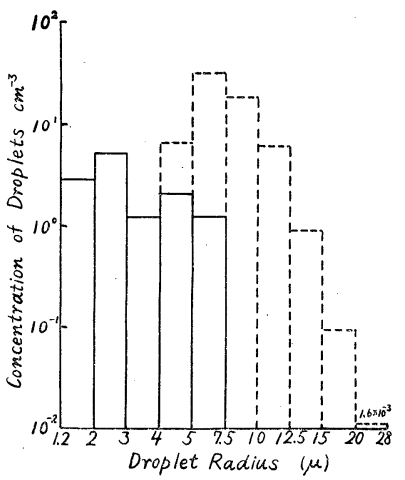

(b) City office, 0523-0529 JST

Fig. 2.14. Droplet size distributions on Mar. 10, 1960.

Gravity settling method

Impactor method 
Table 2.1 Data of fog on March 10, 1960.

\begin{tabular}{|c|rrrrr|}
\hline Place & \multicolumn{5}{|c|}{ Shunkocho } \\
\hline Time (JST) & 0237 & 0300 & 0320 & 0348 & 0406 \\
L.W.C. g/m ${ }^{3}$ & 0.087 & 0.30 & 0.097 & 0.27 & 0.085 \\
M.V.R. $\mu$ & 10 & 12 & 10.5 & 11 & 10 \\
Droplet Concentration cm ${ }^{-3}$ & 42 & 69 & 41 & 65 & 44 \\
Visibility m & 300 & 99 & 270 & 100 & 280 \\
Max. Droplet Radius $\mu$ & 27 & 27 & 27 & 25 & 36 \\
Min. Droplet Radius $\mu$ & 1 & 1 & 1.7 & - & 2 \\
S.D.C. cm ${ }^{-3} r<2 \mu$ & 5.7 & 0.6 & 1.7 & - & 0 \\
\hline Place & \multicolumn{3}{|c|}{ City Office } & Asahi Bridge \\
\hline Time (JST) & 0502 & 0516 & 0526 & 0602 & 0612 \\
L.W.C. g/m ${ }^{3}$ & 0.14 & 0.14 & 0.13 & 0.19 & 0.16 \\
M.V.R. $\mu$ & 10 & 9 & 11 & 13.5 & 13 \\
Visibility m & 51 & 65 & 65 & 38 & 31 \\
Droplet Concentration cm ${ }^{-3}$ & 170 & 160 & 180 & 240 & 200 \\
Max. Droplet Radius $\mu$ & 23 & 18 & 28 & 32 & 27 \\
Min. Droplet Radius $\mu$ & 2 & 2 & 1.2 & 1.5 & 3 \\
S.D.C. cm ${ }^{-3} r<2 \mu$ & 0 & 0 & 2.8 & 1.3 & 0 \\
\hline
\end{tabular}

L.W.C.: Liquid Water Content, M.V.R.: Mean Volume Radius,

S.D.C. : Small Droplet Concentration

radius are larger at the Asahi Bridge than at the other two places. It indicates that even in winter fog the local difference of the structure of fog is very small if the fog is well developed. At the Asahi Bridge the samplings were made at about seven meters above river surface. It is frequently mentioned that river has large influence on the formation of fog. But our observations indicate that the influence, even if it exists, is small in well developed radiation fog.

\section{10 Summary}

The measurements by means of a hand operated impactor and water-blue dye coated film reveal that many small droplets of radii less than 2 microns are frequently present in winter fog especially in "smog". The concentration of the small droplets formed in the evening in polluted air gradually decreases, then very few such small droplets are found in the early morning of the following day. It is further found that the local difference of fog structure and the effect of river steam are small in well developed radiation fog.

\section{References}

Eldridge, R.G. (1957): Measurements of cloud drop-size distribution. Journ. Met., 14, 55-59.

Findeisen, W. (1932): Messungen der Grösse und Anzahl der Nebeltropfen zum Studium der Koagulation inhomogenen Nebels. Beitr. Geophys., 35, 295.

Houghton, H.G. and W.H. Radford (1938): On the Measurement of Drop Size and Liquid Water Content in Fogs and Clouds. Papers Phys. Ocean. Met., 6, No. 4.

Kamiyama, K. and M. Moriguchi (1952): The Collection of Fog Droplets upon Fine Fibre and Absorption of Infra-Red Ray by Fog Droplets. Journ. Met., Res., 4, Suppl., 43-53 (in Japanese).

Kumai, M. (1951): Electron microscope study of snow-crystal nuclei. Journ. Met., 8, 151-156.

Liddell, H.F. and N.W. Wootten (1957): The detection and measurement of water droplets. Quart. Journ. Roy. Met. Soc., 83, 263.

Okita, T. (1958): Water-blue film method for measurement of cloud and fog droplets. Journ. Met. Soc. Japan, 36, 164-165.

Okita, T. (1961): Size distribution of large droplets in precipitating clouds. To be published in Tellus. 
Ranz, W.E. and J.B. Wong (1952): Jet impactors for determining the particle-size distributions of aerosols. Arch. Ind. Hyg. Occup. Med., 5, 464.

\title{
霧の物 理 的構造について
}

\author{
大 喜 多 敏 一 \\ （国立公衆衛生院労働衛生学部）
}

旭川でウオーターブルーフイルム法を用いて霧粒の調査を行なつた。気温が $0^{\circ} \mathrm{C}$ 以上の時には mean volume radius は $12.5 \sim 15 \mu$ であるが, 気温が $-5^{\circ} \mathrm{C}$ 以下になると mean volume radius は約 $7.5 \mu$ となる。また冬 霧の場合飞は霧水量は $10^{-4} \sim 10^{-2} \mathrm{~g} / \mathrm{m}^{3}$ であ霧の状態のことがしばしばみられる。このような場合には微粒子が多 数存在することが考えられる。

一方インパクターを用いて霧の中の小滴を観測した。その結果 smog と呼ばれるような冬の霧や蒸気霧中には半 径 $2 \mu$ 以下の小滴が多く存在することがわかつた。またよく発達した放射霧中では川の蒸気の影響があまり大きく ないことあわかつた。 